\title{
Phenotypic Diversity and Pest Management of Potato Varieties Grown at Baffa Mansehra
}

\author{
Irfan Ullah", 4, 5, Azhar Hussain Shah", Zahid Khan', 3,5, Muhammad Ihsan², \\ Hanif Khan', Umar Zeb ${ }^{1}$, Abdur Raqib ${ }^{5}$, Haroon$^{1}$, Peng Zhao ${ }^{1 *}$ \\ ${ }^{1}$ College of Life Sciences, Northwest University, Xi'an, China \\ ${ }^{2}$ College of Urban and Environmental Sciences, Northwest University, Xi'an, China \\ ${ }^{3}$ Department of Zoology, Hazara University Mansehra, Khyber Pakhtunkhwa, Pakistan \\ ${ }^{4}$ Department of Botany, Hazara University Mansehra, Khyber Pakhtunkhwa, Pakistan \\ ${ }^{5}$ Agriculture Research Station, Baffa, Mansehra, Khyber Pakhtunkhwa, Pakistan
}

Received: 2 April 2019

Accepted: 6 August 2019

\begin{abstract}
In the present study, six potato varieties (Evora, Hannat white, Lacetta, Mustang, SH-5, Anats) were evaluated for phenotypic diversity and pest management based on various qualitative and quantitative traits. Data on various morphological traits and insect/pest infestation frequencies were compile for three plants of each variety. Statistical investigation of data showed significant variations in different morphological characteristics such as plant height, leaf length, leaf width, tuber diameter, and tuber yield, and insects/frequencies (aphids, leafhopper, thrips and whiteflies). Our results showed that despite the maximum infestation frequency for aphids (20.80 insect/plot), leafhopper (24.22 insect/plot), thrips (11.09 insect/plot) and whiteflies (15.73), significantly higher plant height $(22.65 \mathrm{~cm})$, leaf length $(6.20 \mathrm{~cm})$, leaf width $(4.66 \mathrm{~cm})$, tuber diameter $(3.43 \mathrm{~cm})$, and tuber yield $(12.80 \mathrm{~kg})$, of Lacetta (v.no3) revealed, indicating that this variety is highly resistant/tolerant to these insects/pests. While SH-5 was second to it as regards insect infestation rate and yield, potato varieties Hannat white showed minimum plant height $(18.18 \mathrm{~cm})$, leaf length $(4.09 \mathrm{~cm})$, leaf width $(3.41 \mathrm{~cm})$, tuber diameter $(2.41 \mathrm{~cm})$, and tuber yield $(7.55 \mathrm{~kg})$, with lowest infestation frequencies for aphids (14.43 insects per plot), leafhopper (17.72 insects/plot), thrips (7.22 insects/plot), and whiteflies (12.97 insects/plot), indicating that this variety is more susceptible to various insects. Based on these results, the varieties Lacetta and SH-5 should be recommended for the cultivation of agro-climatic conditions of Mansehra in order to get maximum yield and to protect the environment and human health from the adverse effects of insecticides and pesticides.
\end{abstract}

Keywords: diversities, pest management, leaf length, leaf width, tuber diameter, tuber yield

*e-mail: Pengzhao@nwu.edu.cn 


\section{Introduction}

After wheat, maize, and rice, the potato is one of the world's most important crops [1, 2]. The Solanum tuberosum L. with few more species (Solanales: Solanaceae) is the second-most comprehensive staple food crop of the world. The potato was first domesticated in high altitude regions of South America, and now the greatest diversities of potato are cultivated in China, India, the Russian Federation, Ukraine, United States. Germany, Bangladesh, Poland, and Europe [3].

In Pakistan three crops of potato are annually produced, i.e., summer crop in the hills and autumn-spring in the planes. The potato is grown over an area of (133435 hectares) in Pakistan with the production of (2581554 thousand tons), while in Khyber Pakhtunkhwa (KP) the potato is grown over an area of (9655 hectares) with a yield of (129529 tons). The crops play a significant role in GDP $[4,5]$. KP accounts for $9 \%$ of the total area and $7.2 \%$ of the production of potatoes in the country. The shares of spring, summer and autumn crops in the production are estimated at 10,15 and $75 \%$, respectively. Though three crops of potatoes are produced in Pakistan, the yielded ratio is still deficient as compared to other potato-growing countries [6-8].

The potato is the world's number-one non-grain food product, and already an essential part of the global food system with production reaching up to 325 million tons $[9,10]$. In growing countries, potato eating is increasing intensely, which currently accounts for more than half of the global yield, where the potato's easiness of crop growing and high energy content have made it a valued cash crop for millions of farmers [11, 12]. They are known for its carbohydrate content nutritionally, and the major form of this carbohydrate is starch [1, 13-15]. Potatoes have been identified as vital to human nutrition because they contain minerals and vitamins and a group of phytochemicals such as polyphenols and carotenoids. A medium-sized potato of $150 \mathrm{~g}$ provides about $0.2 \mathrm{mg}$ vitamins, $27 \mathrm{mg}$ of vitamin $\mathrm{C}$ and $620 \mathrm{mg}$ of potassium. The average potatoes composition is about $18 \%$ starch, $2 \%$ protein and $80 \%$ water. It is one of the cheapest and most readily available sources of protein and an appreciable amount of vitamins B and C, some minerals, carbohydrates and protein that is of high biological value [16-18].

For potato production cold summer temperatures, sufficient soil moisture for maximum yields $[19,20]$ and its tuber formation is favoured by high application rates of nitrogen, potash, and phosphorus along with other essential nutrients for best yields in most locations, while magnesium usually is needed in acidic soils; however, moderately fertile soil is necessary for the best growth of potato tubers [21].

The main reason for low production might be the cultivation of non-certified seeds of different potato varieties vulnerable to various viral, bacterial, insect and pest damage [22]. Virus damage, bacterial ring rot, early blight and late blight are diseases that attack potatoes, but the most severe is the Colorado potato beetle, which can inflict enormous foliar damage on the crop. Leafhoppers, aphids, potato flea and beetles are insects that destroy the crops [23-25]. Within 2-4 months the potato tuber moth can inflict crop losses of up to $100 \%$. Devoid of suitable control, this pest is considered the main constraint to potato production [26-28]. The green peach (peach-potato) aphid and Myzuspersicae (Sulzer) are the most destructive pests of potatoes, while whiteflies (Homoptera: Aleyrodidae) are severe pests of several crops, including potato, okra and cotton [29, 30], and many vegetables, i.e. bitter gourd, okra and potato, which can be severely damaged by whiteflies, and they can also cause a significant loss to potato crop production [31-33].

To control the damage caused by aphids, leafhoppers, whiteflies, and thrips, pesticides and herbicides are intensively used, but safety tools are often inadequate, and adherence to conduct on distribution and use of pesticides is poorly managed [34, 35]. Environment and human health are adversely affected by pesticide use, making potato production unmaintainable day by day. Therefore, it is necessary to develop an alternate method of pest control $[36,37]$. The most reliable and sustainable strategy/approach could be built to control alternatives for managing pest problems [38], although to grow more capable crops under biotic stresses such as viruses, bacteria, insect and pest [39-41], which responded to various insect and pest $[42,43]$ invaders, while in developing countries farmers have cultivated insect/pest-resistant crops [44, 45].

The morphological representation is the main step that explains the genetic makeup within the species and helps to select better genotypes/cultivars with desirable traits. Keeping this in view in a contemporary piece of work, an attempt has been made to evaluate six potato varieties for phenotypic diversity against different species of insects to control pests with the following objectives: (a) to evaluate the performance of potato varieties in the field conditions, (b) to find the relatively resistant and susceptible varieties against major insect pests and (c) to recommend the high-yielding varieties based on field performance.

\section{Materials and Methods}

Six potato varieties - Evora, Hannat White, Lacetta, Mustang, SH-5 and Anats - were assembled from NARC, Islamabad and sown as ordinary seasonal crops with standardized cultural and agronomic methods to assess the phenotypic diversity and pest management of potato cultivars grown under Mansehra's agro-climatic circumstances at the Agriculture Research Station in Baffa, Mansehra during October 2012-January 2013. 
Table 1. Effect of phenotypic diversity on plant height $(\mathrm{cm})$, leaf length $(\mathrm{cm})$, leaf width $(\mathrm{cm})$, tuber diameter $(\mathrm{cm})$ and yield $(\mathrm{kg})$ of the potato crop.

\begin{tabular}{|c|c|c|c|c|c|c|}
\hline V. No & Varieties & PH & LL & LW & TD & Y \\
\hline 1 & Evora & $21.20 \mathrm{C}$ & $5.00 \mathrm{C}$ & $4.37 \mathrm{C}$ & $3.11 \mathrm{C}$ & $10.73 \mathrm{C}$ \\
\hline 2 & Hannat white & $18.18 \mathrm{~F}$ & $4.09 \mathrm{~F}$ & $3.41 \mathrm{~F}$ & $2.41 \mathrm{~F}$ & $7.55 \mathrm{~F}$ \\
\hline 3 & Lacetta & $22.57 \mathrm{~A}$ & $6.20 \mathrm{~A}$ & $4.66 \mathrm{~A}$ & $3.43 \mathrm{~A}$ & $12.80 \mathrm{~A}$ \\
\hline 4 & Mustang & $20.82 \mathrm{E}$ & $4.7 \mathrm{E}$ & $3.94 \mathrm{E}$ & $2.61 \mathrm{E}$ & $7.80 \mathrm{E}$ \\
\hline 5 & SH-5 & $21.29 \mathrm{~B}$ & $5.01 \mathrm{~B}$ & $4.53 \mathrm{~B}$ & $3.16 \mathrm{~B}$ & $12.50 \mathrm{~B}$ \\
\hline 6 & Anats & $20.82 \mathrm{D}$ & $4.72 \mathrm{D}$ & $4.24 \mathrm{D}$ & $2.96 \mathrm{D}$ & $9.90 \mathrm{D}$ \\
\hline LSD & $0.05 \%$ & 1.116 & 0.5177 & 0.2907 & 0.2748 & 1.1339 \\
\hline
\end{tabular}

PH plant mean height, LL Leaf length, TD Tuber diameter, A, B, C, D, E, and F, Means followed by different letter(s) are significantly different from each other in each category at $\mathrm{Pvalue}<0.05$ should be $\mathrm{PH}$ plant height, LL leaf length, TD tuber diameter, A, B, C, D, E and F, means followed by different letter(s) are significantly different from each other in each category $\mathrm{P}_{\text {value }}<0.05$

\section{Experimental Site and Field Operations}

The experiment was carried out with three replications in randomized complete block design (RCBD) to reduce experimental errors. The range between lines was $60 \mathrm{~cm}$, and the distance between plants was $30 \mathrm{~cm}$. Each genotype's subplot was comprised of 4 rows. The total experimental area was 37791.36/sqm. On October 9, 2012, sowing was conducted and contested.

\section{Parameters Studied}

Three crops were randomly chosen from each line of each cultivar's subplot to record experimental information. Due to the enlisted parameters, the selected plants were marked and used for further findings. The information collected from each plot was measured and displayed to interpret the outcomes of the corresponding parameters in the shape of lists. Plant height $(\mathrm{cm})$, leaf length $(\mathrm{cm})$, leaf width, tuber colour and tuber diameter were taken into consideration used the average of a measuring tape, ruler, vernier calliper and tuber colour percentage was calculated. Finally, the yield of potato tuber/plot was determined in a kilogram, by weighing

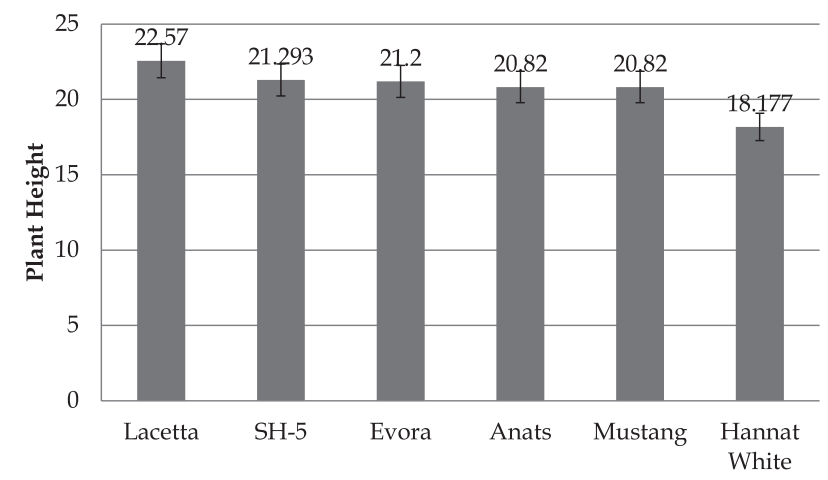

Fig. 1. Plant heights $(\mathrm{cm})$ of different potato cultivars. four rows from each subplot at the time of uprooting of the crop.

\section{Pest Management}

From selected potatoes, the pest management strategy was used against the infestation of sucking insect pest of potato, including leafhopper (Empoasca fabae), silverleaf whitefly (Bemisia tabaci), potato aphid (Macrosyphum euphorbiae) and potato thrips (Thrips tabaci) of different potato cultivars (Lacetta, SH-5, Evora, Anats, Mustang, and Hannat white) were tested for their comparative characteristics of insect repellants/resistance/tolerance. During the whole period from sowing to maturity and harvest, crops remained under close observation for insect pest activities. The data were analysed through Statistix 8.1 and SPSS 16.0 software.

\section{Results and Discussion}

\section{Plant Height}

Data Regarding plant height is presented in (Table 1, Fig. 1). Statistical analysis of the data revealed that plant height was significantly $(P=0.0493$ affected by phenotypic diversity of potato crop). Maximum plant height $(22,57 \mathrm{~cm})$ was noted in Lacetta cultivar, followed by SH-5 $(21,29 \mathrm{~cm})$, equivalent to Evora $(21,20 \mathrm{~cm})$, Anats $(20,82 \mathrm{~cm})$ and Mustang $(20,82$ $\mathrm{cm})$ respectively. All these cultivars were discovered to differ considerably from Hannat white (achieving $18.18 \mathrm{~cm}$ height), but were indifferent to each other.

\section{Leaf Length}

The leaf length data means are shown (Table 1, Fig. 2). Statistical analysis showed significant 


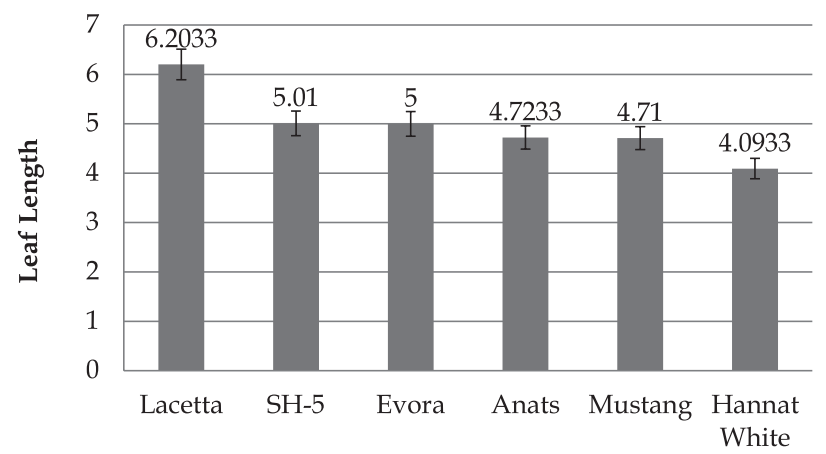

Fig. 2. Leaf lengths $(\mathrm{cm})$ of different potato cultivars.

differences in the leaf duration of tested potato cultivars $(\mathrm{P}=0.0399)$. In Lacetta cultivar, maximum plant span $(6.20 \mathrm{~cm})$ was reported, accompanied by $5.01 \mathrm{SH}-5$. While in Hannat white, the minimum flower length (4.09) was reported. Furthermore, the results revealed that the Lacetta cultivar was significantly different in terms of leaf length from the other varieties, but the leaf length of the rest of the cultivars was not significantly different.

\section{Leaf Width}

In Table 1, Fig. 3, the experimental data on the leaf width of the tested potato cultivars are presented. Statistical analysis showed important differences in the distinct cultivars' stem length $(\mathrm{P}=0.02)$. Lacetta noted maximum leaf width $(4.66 \mathrm{~cm})$, followed by SH-5 leaf width $(4.53 \mathrm{~cm})$, while Hannat white noted the lowest leaf width $(3.41 \mathrm{~cm})$. Lacetta differed substantially from all other cultivars. While SH-5, Evora, and Anats leaf width were statistically similar but different from the rest of the cultivars.

\section{Tuber Colour}

In Lacetta, SH-5, Evora, Annats, Mustang and Hannat white, different tuber colors such as white creamy, dark red, white, creamy, red white and light white were recorded. The largest proportion (28.6\%) of creamy color was found in Anats, followed by SH-5

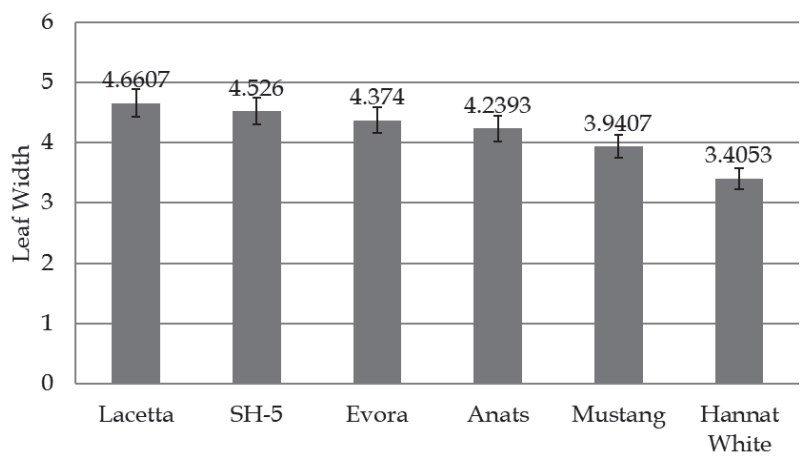

Fig. 3. Leaf lengths $(\mathrm{cm})$ of different potato cultivars.

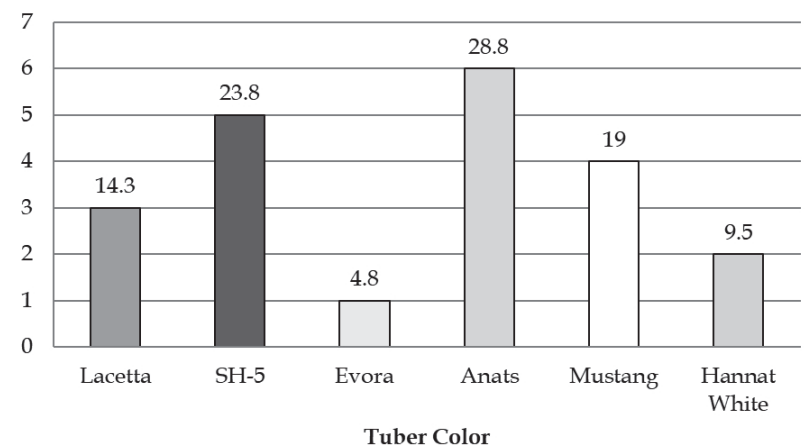

Fig. 4. Effect of phenotypic diversity on tuber colours of the potato crop.

(23.8\%) of dark reddish colour, Mustang (19\%) of white colour, Lacetta (14.3\%) of reddish white colour, and Hannat white $(9.5 \%)$ of light white colour, while the smallest proportion was found in Evora (4.8\%) of creamy white colour.

\section{Tuber Diameter}

The data regarding the diameters of the potato tubers are presented in Table 1 and Fig. 5. Data statistical assessment showed important variability in tuber size diameter $(\mathrm{P}=0.0360)$ among the cultivars studied. Maximum tuber diameter $(3.43 \mathrm{~cm})$ accompanied by SH-5, (3.16 cm) Evora, (3.11 cm) Anats, (2.96) Mustang and (2.61) were noted in Lacetta. However, Lacetta's tuber diameter was discovered to differ considerably from Mustang and white Hannat. The data also showed that in cultivar Hannat white, which reached diameter $2.41 \mathrm{~cm}$, the minimum tuber diameter was noted, but it was statistically similar to Anats and Mustang.

\section{The Yield of Potato Tuber/Plot}

For individual replication, the output of potato tubers was determined individually and then averaged for each therapy and shown in Table 1 an Fig. 6. Analysis of data revealed that tuber yield $(\mathrm{P}=0.0031)$ was significantly affected by potato crop phenotypic

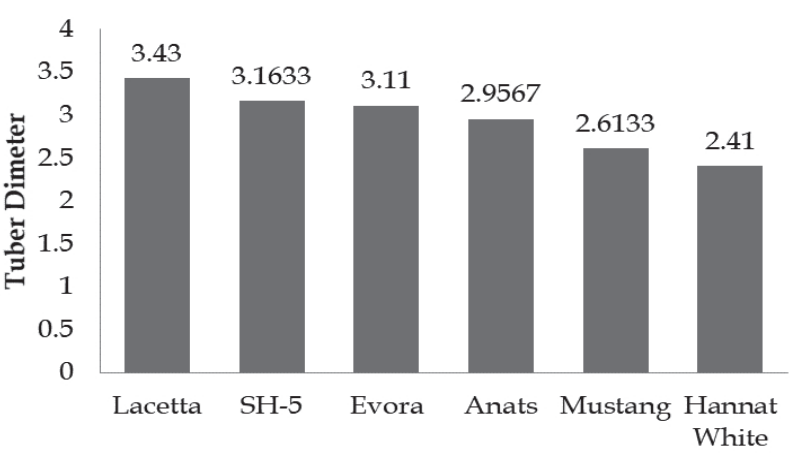

Fig. 5. Measurement of tuber diameter in $(\mathrm{cm})$ of different potato cultivars. 


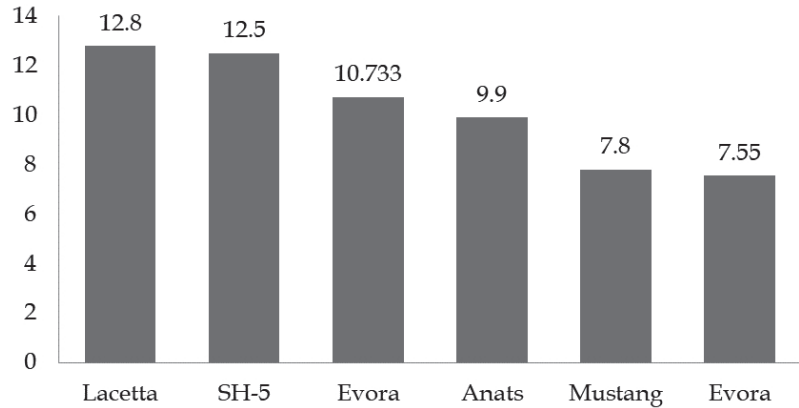

Fig. 6. Comparative yield of phenotypically diversity potato cultivars.

diversity. Nevertheless, the maximum $(12,80 \mathrm{~kg})$ tubers were recorded in the Lacetta variety, which was almost equal to SH-5, having $(12,50 \mathrm{~kg})$ potato tubers per plot. Statistically, Lacetta was not substantially distinct from SH-5 and Evora, but considerably distinct from Anats, Mustang, and white Hannat. On the other side, the minimum yield $(7.55 \mathrm{~kg})$ of fruit was acquired from the Hannat white type, which was almost equal to the Mustang cultivar, which produced fruit $(7.80 \mathrm{~kg})$. Both species' output was not substantially distinct from the Anats, but was considerably smaller than that of Lacetta, and SH-5.

\section{Aphids}

Data on the incidence of aphid crop are shown in Table 2 and Fig. 7. Statistical analysis of the data shows that the potato cultivars tested significantly affected the aphid population $(\mathrm{P}=0.0459)$ by phenotypic diversity. The highest population was reported in Lacetta cultivar (20.80/plot), followed by SH-5, enumerating the amount of aphid individuals and nymphs (20.73/plot). However, the varieties Lacetta, SH-5, Evora, and Anats were found to be statistically similar with respect to the incidence of aphid population densities, in contrast to the lowest population density with the seasonal average of (14.44 insects/plot) recorded in Hannat white cultivar and which were statistically different from the rest of

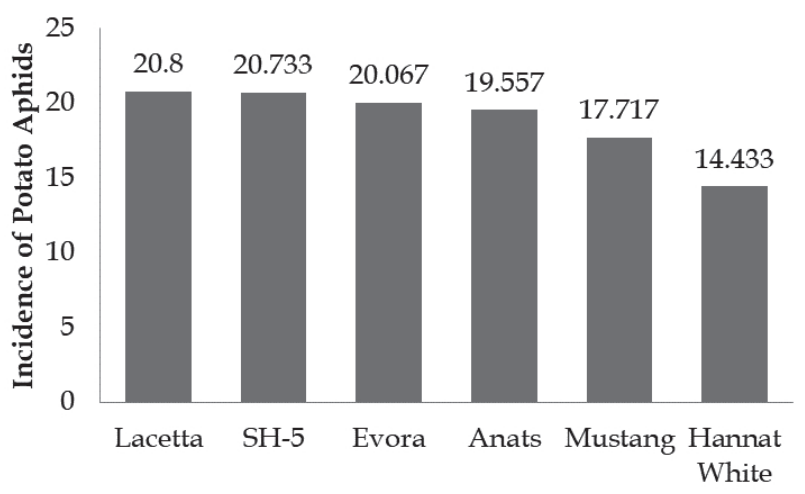

Fig. 7. Incidence of potato aphids.

the cultivars. Therefore, this variety may be considered the most resistant/repellant to the potato aphids. While cultivar Mustang (17.72 aphids) showed second to it per plot.

\section{Leafhopper}

Data on the demographic density of potato Leafhoppers (Table 2, Fig. 8) disclosed that the frequency of infestation was considerably influenced under normal soil circumstances $(\mathrm{P}=0.0234)$ by the phenotypic variety of the studied cultivars. A maximum number of the pest was enumerated as (24.22 per/plot) in cultivar Lacetta, which was statistically at par with SH-5, Evora, and Anats, but significantly higher than Mustang, and Hannat white. While minimum infestation was observed in cultivars Hannat, white showing 17.72 hoppers per cultivar followed by Mustang, receiving average infestation of 17.77 throughout the study period. Hannat white was not significantly different from mustang but was different from the remaining tested cultivars.

\section{Thrips}

Data on the demographic concentration of potato thrips are provided during the research era (Table 2, Fig. 9). The population trend of thrips was observed to

Table 2. Effect of phenotypic diversity on aphid, incidence of leafhopper, thrip and whitefly infestation of potato crop.

\begin{tabular}{|c|c|c|c|c|c|}
\hline V. No & Varieties & Aphid & Leafhopper & Thrips & Whiteflies \\
\hline 1 & Evora & $20.07 \mathrm{C}$ & $23.16 \mathrm{C}$ & $10.48 \mathrm{C}$ & $15.15 \mathrm{C}$ \\
\hline 2 & Hannat white & $14.43 \mathrm{~F}$ & $17.72 \mathrm{~F}$ & $7.22 \mathrm{~F}$ & $12.97 \mathrm{~F}$ \\
\hline 3 & Lacetta & $20.80 \mathrm{~A}$ & $24.21 \mathrm{~A}$ & $11.09 \mathrm{~A}$ & $15.73 \mathrm{~A}$ \\
\hline 4 & Mustang & $17.72 \mathrm{E}$ & $17.77 \mathrm{E}$ & $8.39 \mathrm{E}$ & $14.10 \mathrm{E}$ \\
\hline 5 & SH-5 & $20.73 \mathrm{~B}$ & $23.78 \mathrm{~B}$ & $10.83 \mathrm{~B}$ & $15.70 \mathrm{~B}$ \\
\hline 6 & Anats & $19.56 \mathrm{D}$ & $22.94 \mathrm{D}$ & $10.06 \mathrm{D}$ & $14.73 \mathrm{D}$ \\
\hline LSD & $0.05 \%$ & 0.9392 & 2.0516 & 0.9803 & 0.8191 \\
\hline
\end{tabular}

A, B, C, D, E and F, means followed by different letter(s) are significantly different from each other in each category at $\mathrm{P}_{\text {value }}<0.05$ 


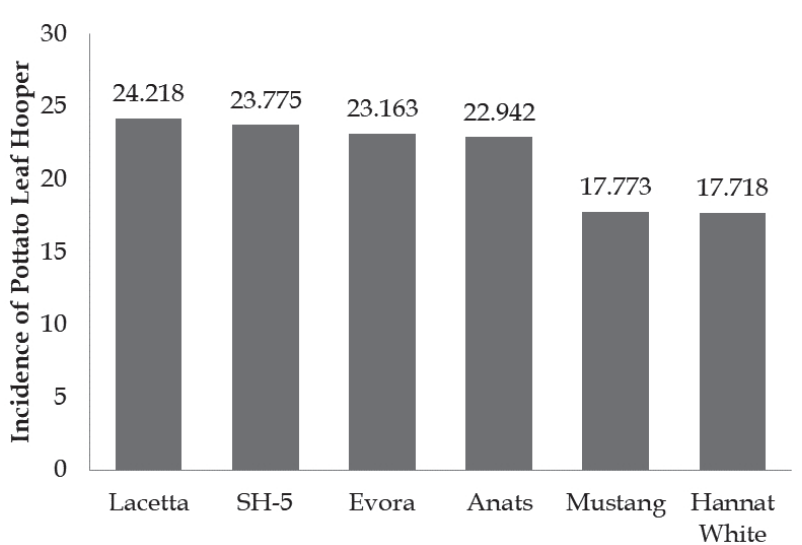

Fig. 8. Incidence of potato leafhoppers.

be significantly affected $(\mathrm{P}=0.0077)$ by the phenotypic diversity of the tested cultivars. The impacts, however, were not as uniform. Cultivars Lacetta recorded a maximum of 11.09 (larvae per plot) infestation, accompanied by SH-5 showing 10,830 larvae (adults and nymphs). The insects were not significantly different from SH-5, Evora, and Anats on the Lacetta variety, but were significantly different from Mustang and Hannat white. Likewise, the Hannat white range got the smallest potato thrips infestation displaying 7.22 insects/plot while mustang got 8.39 insects/plot infestation. Based on population density of thrips and phenotypic structures of distinct leaf cultivars, the Lacetta cultivar was proven to be the most resistant to potato thrips as opposed to Hannat white, which was proven to be the most vulnerable among the cultivars studied. Mustang cultivars was also considerably less susceptible to Hannat white cultivar.

\section{Whitefly}

The relative amount of whitefly on the studied cultivars (regardless of the phase of growth of its life cycle) is shown in Table 2 and Fig. 10. Data analysis disclosed that the insect population at $(\mathrm{P}=0.0488)$ was considerably influenced by the screened cultivars phenotypic variety. In Lacetta, the maximum infestation

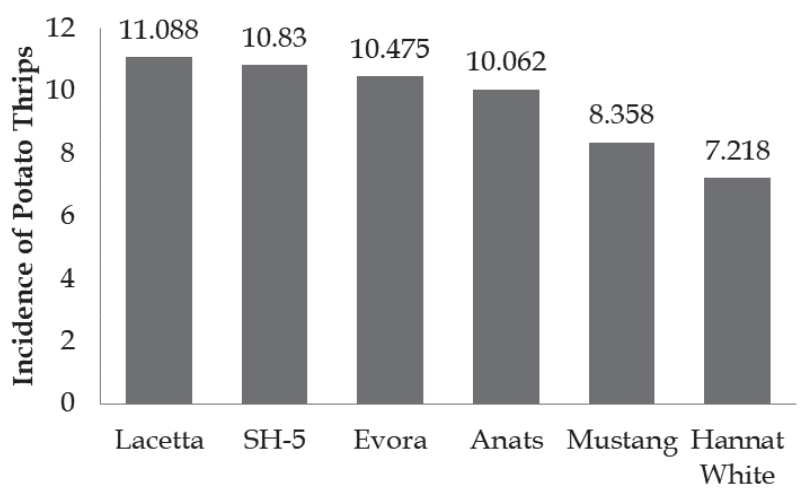

Fig. 9. Incidence of potato thrips.

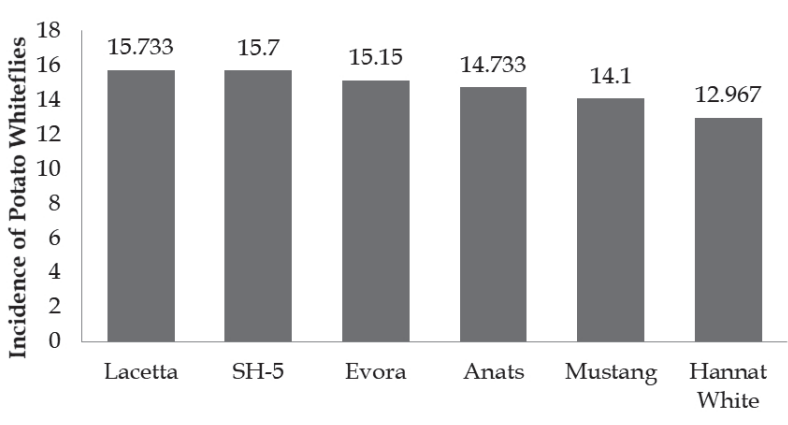

Fig. 10. Incidence of potato whiteflies.

(15.73/plot) was observed. It was on par with all other types, except for cultivar Hannat white, which was statistically distinct with the smallest (12.97) organisms/ plot. Furthermore, statistical analysis showed that Hannat white differed considerably from Evora, SH-5, and Lacetta.

The research was scheduled on the basis of RCBD structure to verify distinct insect/pest resistance/ tolerance to various potato types during October 2012-January 2013. Our findings showed essential differences in the frequency of infestation of plants and insects between distinct varieties of potatoes. Maximum plant height was noted in Lacetta (22.57), Hannat white (18.19) and highest insect infestation per insect, Aphids (20.80), Leafhopper (24.22), Thrips (11.09) and Whiteflies (15.73), accompanied by SH-5 (21.29) in lacetta; Evora, (21.20), respectively Anats (20.82), and Mustang (20.82). These findings demonstrated that the frequency of infestation of insects was immediately proportional to the plant's development. This may be because they are more vulnerable to multiple insects/ pests as crops develop quickly. These results are consistent with the findings of $\mathrm{n}$, who reported similar results in potato. Our results further disclosed that, despite the highest infestation rates of all insects, the peak development of Lacetta and $\mathrm{SH}-5$ proved that these varieties are most resistant/tolerant, while the minimum growth of Hannat white with the highest infestation rates for Aphid (14.43), Leafhopper (17.72), Thrips (7.22) and Whitefly (12.97) found this range to be more prone to different insects/pests. These findings are consistent with Syfert et al. [47], who found that these species were more likely to be impacted by insects.

The present results showed significant variations among leaf length and insect infestation rate among different potato varieties. Maximum leaf length was observed in Lacetta (6.20), while minimum in Hannat white (4.09), and maximum insect infestation per insects, Aphids (20.80), Leafhopper (24.22), Thrips (11.09), and Whiteflies (15.73) was recorded in lacetta, followed by SH-5, (5.01), Evora, (5.00), Anats (4.72), and Mustang (4.71). These finding showed that higher leaf growth results in more exposure to leaf length to various insects/pests. These results are consistent with the findings of $[48,49]$, who reported similar results 
in potato. Current research revealed that maximum leaf growth of Lacetta and SH-5, despite of maximum infestation frequencies of all the insects, showed that these varieties are resistant/tolerant to these insects/pests, while minimum leaf length of Hannat white with lowest infestation frequencies for Aphid (14.43), Leafhopper (17.72), Thrips (7.22), and Whitefly (12.97), revealed that this verity is more susceptible to various insects/pests. These results are in agreement with the findings of Donatelli et al. [50], who reported that insects cause poor development of leaf and as a whole on the plant due to which tuber growth is affected.

Therefore, we concluded the significant variations among leaf width and insect infestation rate among different potato varieties. Maximum insect infestation per insect for Aphids (20.80), Leafhopper (24.22), Thrips (11.09), and Whiteflies (15.73) was recorded in Lacetta, followed by SH-5, (4.53), Evora, (4.37), Anats (4.24), and Mustang (3.94) respectively. Our findings further revealed that maximum leaf width growth of Lacetta, and $\mathrm{SH}-5$, despite maximum infestation frequencies of all the insects, showed that these varieties may be most resistant/tolerant, while minimum leaf width growth of Hannat white with lowest infestation frequencies for Aphid (14.433), Leafhopper (17.72), Thrips (7.22), and Whitefly (12.97), revealed that this variety is more susceptible to various insects/pests. These results agreed with the findings of Ventrella et al. [51], who reported similar results in potato.

There were significant variations among tuber diameter and insect infestation rate among different potato varieties. Maximum tuber diameter was observed in Lacetta (3.43), while minimum in Hannat white (2.41), and maximum insect infestation per insect, Aphids (20.80), Leafhopper (24.22), Thrips (11.09), and Whiteflies (15.73), was recorded in lacetta, followed by SH-5, (3.16), Evora, (3.11), Anats (2.96), and Mustang (2.61). These findings showed that as plants proliferate, they are more exposed to sunlight, and as a result photosynthetic activity increased, providing more nutrients/food to plants that ultimately increased tuber diameter. But this is only possible if the plants are resistant/tolerant like Lacetta and $\mathrm{SH}-5$, various insects otherwise their growth and tuber diameter are adversely affected by insect infestation (Hannat, white and Mustang). These results are consistent with the findings of Golizadeh et al. [52], who reported similar results in potato. These results are in agreement with the finding of Kroschel et al. [53], who reported that insect infestation rate is directly proportional with the tuber diameter of Solanum tuberosum, and the high infestation rate of insects showed less tuber diameter.

Our results showed significant variations among yield of potato tuber/plot and insect infestation rate among different potato varieties. Maximum yield was observed in Lacetta $(12.80 \mathrm{~kg})$, while minimum in Hannat white $(7.55 \mathrm{~kg})$, and maximum insect infestation per insects, Aphids (20.80), Leafhopper (24.22), Thrips (11.09), and Whiteflies (15.733), was recorded in lacetta, followed by SH-5, (12.500kg), Evora, (10.73 kg), Anats $(9.90 \mathrm{~kg})$, and Mustang $(7.80 \mathrm{~kg})$ respectively. These finding showed that tuber yield is directly proportional to plant growth, leaf length, leaf width and tuber diameter and insect infestation rate. These results are consistent with the findings of [53, 54], who reported similar results in potato. Our findings further revealed that maximum yield of Lacetta and $\mathrm{SH}-5$, despite maximum infestation frequencies of all the insects, showed that these varieties are most resistant/tolerant, while minimum growth of Hannat white showed lowest infestation frequencies for Aphid (14.43), Leafhopper (17.72), Thrips (7.22), and Whitefly (12.97) [53]. These results are in agreement with the findings of [53, 55], who reported that Lacetta and SH-5 are tolerant to the high infestation rate of insects in case of the total yield of the potato crop.

\section{Conclusions}

The general findings of the current investigations have led us to the conclusion that the output elements of plant cultivars are significantly affected by phenotypic variety and pest management. All potato cultivars were subjected to pests, and therefore Lacetta was discovered to be more producing, with a complete output of 36 (kg/crop), followed by SH-5, 32.182 (kg/crop), Evora $(30,718 \mathrm{~kg} / \mathrm{crop})$, while Anats $(29,36 \mathrm{~kg} / \mathrm{crop})$ and Mustang $(28,108 \mathrm{~kg} / \mathrm{crop})$ were relatively less tolerant/ resistant, while Hannat white $(23,346 \mathrm{~kg} / \mathrm{crop})$ was discovered to be the most susceptible to significant insect/pests of potato.

\section{Acknowledgements}

This study was supported by the Director of Agriculture, Research station, Baffa, Mansehra, Khyber Pakhtunkhwa, Pakistan.

\section{Conflict of Interest}

The authors declare no conflict of interest.

\section{References}

1. LEFF B., RAMANKUTTY N., FOLEY J.A. Geographic distribution of major crops across the world. Global Biogeochemical Cycles, 18, 1, 2004.

2. PRAKASH P., KISHORE P., JAGANATHAN D., IMMANUAL S., SIVAKUMAR P. The Status, Performance and Impact of sweet potato cultivation on farming communities of Odisha, India. In 2018 Conference, July 28-August 2, 2018, Vancouver, British Columbia. International Association of Agricultural Economists, 2018. 
3. BLOM-ZANDSTRA G., SOETHOUDT H., AXMANN H. Value chain analysis of the potato sector in Tunisia: Business opportunities. Wageningen Plant Research, Business Unit Agrosystems Research, 2018.

4. BROADBERRY S., CAMPBELL B., KLEIN A., OVERTON M., VAN LEEUWEN B. British Economic Growth, 1270-1870: an output-based approach, 2011.

5. MAJEED A., MUHAMMAD Z. Potato production in Pakistan: challenges and prospective management strategies - a review. Pak J Bot, 50, 2077, 2018.

6. KHURANA S.P. Indian potato exports: an overview. Potato J, 33, 1, 2006.

7. QASIM M., KHALID S., NAZ A., KHAN M.Z., KHAN S.A. Effects of different planting systems on yield of potato crop in Kaghan Valley: A mountainous region of Pakistan. Agricultural Sciences, 4, 175, 2013.

8. HESAM F., BALALI G.R., TEHRANI RT.. Evaluation of antioxidant activity of three common potato (Solanum tuberosum) cultivars in Iran. Avicenna journal of phytomedicine, 2, 79, 2012.

9. KUMAR P., SINGH B., KUMAR R., KUMAR N. Effect of maturity days on yield and processing quality of potato varieties. Research \& Reviews: Journal of Agricultural Science and Technology, 1, 1, 2018.

10. JATAV A., KUSHWAH S., NARUKA I. Performance of Potato Varieties for Growth, Yield, Quality and Economics under Different Levels of Nitrogen. Advances in Research, 6, 1, 2017.

11. KHAN M., KHAN S. Potential markets of potato: Report of the Trade Development Authority of Pakistan, 2010.

12. MCGILL C.R., KURILICH A.C., DAVIGNON J. The role of potatoes and potato components in cardiometabolic health: a review. Annals of medicine, 45, 467, 2013.

13. PETERS D. Carbohydrates for fermentation. Biotechnology Journal: Healthcare Nutrition Technology, 1, 806, 2006.

14. SINGH N., SINGH J., KAUR L., SODHI N.S., GILL B.S. Morphological, thermal and rheological properties of starches from different botanical sources. Food chemistry, 81, 219, 2003.

15. KING J.C., SLAVIN J.L. White potatoes, human health, and dietary guidance. Advances in Nutrition, 4, 393S, 2013.

16. DAY L. Proteins from land plants-potential resources for human nutrition and food security. Trends in Food Science \& Technology, 32, 25, 2013.

17. HERTRAMPF J.W., PIEDAD-PASCUAL F. Handbook on ingredients for aquaculture feeds. Springer Science \& Business Media, 2012.

18. ROBERTSON T., ALZAABI A., ROBERTSON M., FIELDING B. Starchy Carbohydrates in a Healthy Diet: The Role of the Humble Potato. Nutrients, 10, 1764, 2018.

19. PAPROTKA T., BOITEUX L., FONSECA M., RESENDE R., JESKE H., FARIA J., RIBEIRO S. Genomic diversity of sweet potato geminiviruses in a Brazilian germplasm bank. Virus Research, 149, 224, 2010.

20. JOVOVIC Z., MICEV B., VELIMIROVIC A. Impact of climate change on potato production in Montenegro and options to mitigate the adverse effects. Acad J Environ Sci, 4, 047, 2016.

21. FERNANDES A.M., SORATTO R.P., SOUZA EDFCD, JOB ALG. Nutrient Uptake and Removal by Potato Cultivars as Affected by Phosphate Fertilization of Soils with Different Levels of Phosphorus Availability. Revista Brasileira de Ciência do Solo, 41, 1, 2017.
22. RONDON S.I. Pest management strategies for potato insect pests in the Pacific Northwest of the United States. In Insecticides-Pest Engineering. InTech, 2012.

23. SARWAR M.B. Some Insect Pests (Arthropoda: Insecta) of Summer Vegetables, Their Identification, Occurrence, Damage and Adoption of Management Practices. International Journal of Sustainable Agricultural Research, 1, 108, 2014.

24. IRSHAD G., NAZ MFAF. Important fungal diseases of potato and their management - a brief review. MYCOPATH, 11, 1, 2014.

25. GOOLSBY J.A., ADAMCZYK J., BEXTINE B., LIN D., MUNYANEZA J.E., BESTER G. Development of an IPM program for management of the potato psyllid to reduce incidence of zebra chip disorder in potatoes. Subtropical Plant Science, 59, 85, 2007.

26. MOHAMMED A., DOUCHES D., PETT W., GRAFIUS E., COOMBS J., LISWIDOWATI, LI W., MADKOUR M. Evaluation of potato tuber moth (Lepidoptera: Gelechiidae) resistance in tubers of Bt-cry5 transgenic potato lines. Journal of economic entomology, 93, 472, 2000.

27. KWON M., KIM J., MAHARJAN R., CHOI J.-Y., KIM G.H. Change in the distribution of the potato tuber moth, Phthorimaea operculella (Zeller) (Lepidoptera: Gelechiidae), in Korea. Journal of Asia-Pacific Entomology, 20, 1249, 2017.

28. MULUGETA T., MULATU B., TEKIE H., YESUF M., ANDREASSON E., ALEXANDERSSON E. Phosphite alters the behavioral response of potato tuber moth (Phthorimaea operculella) to field-grown potato. Pest management science, 2018.

29. CHANDEL R., CHANDLA V., VERMA K., PATHANIA $M$. Insect pests of potato in India: biology and management. In Insect pests of potato. Elsevier, 227, 2013.

30. ALHOUSARI F., GREGER M. Silicon and Mechanisms of Plant Resistance to Insect Pests. Plants, 7, 33, 2018.

31. TONG X., PHILIP A. Insecticides activity of surfactants and oils against Ailver Leaf White fly on collards and tomato. P Manag Sci, 56, 861, 2000.

32. MAKETON M., OROSZ-COGHLAN P., HOTAGA D. Field evaluation of metschnikoff (Metarhizium anisopliae) sorokin in controlling cotton jassid (Amrasca biguttula biguttula) in aubergine (Solanum aculeatissimum). Int $\mathbf{J}$ Agri Biol, 10, 47, 2008.

33. OMONGO C.A., NAMUDDU A., OKAO-OKUJA G., ALICAI T., VAN BRUNSCHOT S., OUVRARD D., COLVIN J. Occurrence of Bondar's Nesting Whitefly, Paraleyrodes bondari (Hemiptera: Aleyrodidae), on cassava in Uganda. Revista Brasileira de Entomologia, 62, 257, 2018

34. WYENANDT A. 2016 Mid-Atlantic Commercial Vegetable Production Recommendations, 2016.

35. LACEY L.A., KAYA H.K. Field manual of techniques in invertebrate pathology: application and evaluation of pathogens for control of insects and other invertebrate pests. Springer, 2007.

36. SANKOH A.I., WHITTLE R., SEMPLE K.T., JONES K.C., SWEETMAN A.J. An assessment of the impacts of pesticide use on the environment and health of rice farmers in Sierra Leone. Environment international, 94, 458, 2016.

37. AKTAR W., SENGUPTA D., CHOWDHURY A. Impact of pesticides use in agriculture: their benefits and hazards. Interdisciplinary toxicology, 2, 1, 2009.

38. GREENSTONE M.H., SZENDREI Z., PAYTON M.E., ROWLEY D.L., COUDRON T.C., WEBER D.C. Choosing 
natural enemies for conservation biological control: use of the prey detectability half-life to rank key predators of Colorado potato beetle. Entomologia Experimentalis et Applicata, 136, 97, 2010.

39. LIU Q. Improvement for agronomically important traits by gene engineering in sweetpotato. Breeding science, 67, 15, 2017.

40. PANDEY P., IRULAPPAN V., BAGAVATHIANNAN M.V., SENTHIL-KUMAR M. Impact of combined abiotic and biotic stresses on plant growth and avenues for crop improvement by exploiting physio-morphological traits. Frontiers in plant science, 8, 37, 2017.

41. ARSLANOGLU F., AYTAC S., ONER K. Morphological characterization of the local potato (Solanum tuberosum L.) genotypes collected from the Eastern Black Sea region of Turkey. African Journal of Biotechnology, 10, 922, 2011.

42. CORPAS F.J., ALCHÉ J.D.D., BARROSO J.B. Current overview of S-nitrosoglutathione (GSNO) in higher plants. Frontiers in plant science, 4, 126, 2013.

43. ATKINSON N.J., URWIN P.E. The interaction of plant biotic and abiotic stresses: from genes to the field. Journal of experimental botany, 63, 3523, 2012.

44. MARIANI L., FERRANTE A. Agronomic management for enhancing plant tolerance to abiotic stresses-drought, salinity, hypoxia, and lodging. Horticulturae, 3, 52, 2017.

45. ARIF M., THOMAS P., CROSSLIN J., BROWN C. Agrobacterium-mediated transformation of potato using PLRV-REP and PVY CP genes and assessment of replicase mediated resistance against natural infection of PLRV. Pak J Bot, 41, 1477, 2009.

46. CHEN M., SHELTON A., YE G.-Y. Insect-resistant genetically modified rice in China: from research to commercialization. Annual review of entomology, 56, 81, 2011.

47. SYFERT M.M., SERBINA L., BURCKHARDT D., KNAPP S., PERCY D.M. Emerging new crop pests: ecological modelling and analysis of the south American potato psyllid Russelliana solanicola (Hemiptera: Psylloidea) and its wild relatives. PloS one, 12, e0167764, 2017.

48. STIEGEL S., ENTLING M.H., MANTILLA-CONTRERAS J. Reading the Leaves' Palm: Leaf traits and herbivory along the microclimatic gradient of forest layers. PloS one, 12, e0169741, 2017.

49. AGRAWAL A.A., LAU J.A., HAMBÄCK P.A. Community heterogeneity and the evolution of interactions between plants and insect herbivores. The Quarterly review of biology, 81, 349, 2006.

50. DONATELLI M., MAGAREY R.D., BREGAGLIO S., WILLOCQUET L., WHISH J.P., SAVARY S. Modelling the impacts of pests and diseases on agricultural systems. Agricultural systems, 155, 213, 2017.

51. VENTRELLA E., ADAMSKI Z., CHUDZIŃSKA E., MIĄDOWICZ-KOBIELSKA M., MARCINIAK P., BÜYÜKGÜZEL E., BÜYÜKGÜZEL K., ERDEM M., FALABELLA P., SCRANO L. Solanum tuberosum and Lycopersicon esculentum leaf extracts and single metabolites affect development and reproduction of Drosophila melanogaster. PloS one, 11, e0155958, 2016.

52. GOLIZADEH A., ESMAEILI N., RAZMJOU J., RAFIEE-DASTJERDI H., ZIESMANN J. Comparative life tables of the potato tuberworm, Phthorimaea operculella, on leaves and tubers of different potato cultivars. Journal of insect science, 14, 1, 2014.

53. KROSCHEL J., SCHAUB B. Biology and ecology of potato tuber moths as major pests of potato. In Insect Pests of Potato. Elsevier, 165, 2013.

54. MELAKEBERHAN H., DOUCHES D., WANG W. Interactions of selected potato cultivars and populations of Meloidogyne hapla adapted to the Midwest US soils. Crop science, 52, 1132, 2012.

55. LIN B.B. Resilience in agriculture through crop diversification: adaptive management for environmental change. BioScience, 61, 183, 2011. 
